\title{
Fast-Track Anesthesia untuk Prosedur Kraniotomi Evakuasi Hematom karena Stroke Hemoragik
}

\author{
Bona Akhmad Fitrah*), Bambang Suryono ${ }^{* * *}$, Siti Chasnak Saleh***), Himendra Wargahadibrata $\left.{ }^{* * * *}\right)$ \\ ${ }^{*}$ Departemen Anestesiologi dan Terapi Intensif Rumah Sakit Mayapada Lebak Bulus, ${ }^{* *}$ Departemen Anestesiologi \\ dan Terapi Intensif Fakultas Kedokteran Universitas Gadjah Mada-RSUD Dr. Sardjito Yogyakarta, ${ }^{* * *}$ Departemen \\ Anestesiologi dan Reanimasi Kedokteran Universitas Airlangga-RSUD. Dr. Soetomo, ${ }^{* * * *)}$ Departemen \\ Anestesiologi dan Terapi Intensif Kedokteran Universitas Padjadjaran-RSUP Dr. Hasan Sadikin Bandung
}

\begin{abstract}
Abstrak
Fast-track anesthesia pertama kali dikenalkan pada periode 1990 dengan maksud untuk untuk mencegah kerusakan multi organ, komplikasi dan pemulihan yang cepat. Dengan pemulihan yang cepat diharapkan akan mengurangi penggunaan ruang rawat intensif dan masa tinggal di rumah sakit yang lebih pendek. Prosedur ini bukan sekedar ekstubasi cepat tapi juga bagaimana mengelola secara efektif dan efisien obat obat anestesi di perioperatif. Kondisi preoperatif yang baik, penggunaan obat obatan kerja pendek-menengah dan prosedur yang singkat sangat menentukan kesuksesan fast-track anesthesia. Kami laporkan suatu kasus perdarahan intrakranial, laki-laki 60 th masuk ke IGD dengan keluhan sakit kepala berat, pasien dengan riwayat hipertensi tidak terkontrol, diabetes mellitus dan stroke non hemoragik sebelumnya tahun 2013. GCS E3M6Vafasia. Tekanan darah 180/110 mmHg saat masuk IGD. Dari CT scan kepala didapatkan perdarahan intracerebri pada lokasi temporoparietal kiri. Dilakukan prosedur evakuasi hematom segera. Saat intraoperatif dilakukan teknik balans anestesi antara intravenous anestesi, gas anestesi, analgetik diberikan secara intermiten dan pelumpuh otot diberikan secara kontinyu selama operasi. MAP dipertahankan sekitar 90-110 mmHg. Hemodinamik intraoperatif relatif stabil. Prosedur evakuasi hematom dilakukan selama tiga jam. Dengan pertimbangan kesadaran preoperatif yang baik, prosedur yang tidak terlalu lama, hemodinamik stabil selama operasi, udem jaringan otak yang minimal tidak ada kerusakan jaringan yang berat maka dilakukan ekstubasi dan pasca operasi pasien dirawat di HCU.
\end{abstract}

Kata kunci: efektif dan efisien anesthesia, fast-tract anesthesia, perdarahan intracerebral

JNI 2018;7 (2): 88-95

\section{Fast-Track Anesthesia for Craniotomy Evacution Hemmatoma due to Hemmorhagic Stroke}

Fast-track anesthesia first time introduced in early 1990 with aim to prevent multi organ failure, complication and speedy recovery. With a quick recovery will reduce intensive care unit usage and reduce length of stay in the hospital. It is not just early extubation but also how to manage with effective and efficient anesthesia during perioperative. Good preoperative condition, using short acting drug and short procedure will determinate the successful of fast-track anesthesia. Here we report an intracerebral hemorrhage with fast-track anesthesia. Men, 60 yo attended to the ER with complaining severe headache. Patient with uncontrolled hypertension, diabetes mellitus and stroke non hemorhagic in 2013. GCS when admission E3M6Vaphasia and blood pressure 180/110 mmHg. CT scan showed intracerebral hemmorhage at left temporoparietal. Hematoma evacuation performed urgently. Anesthesia performed with balance anesthesia using intravenous, inhaled anesthesia intermitten intravenous analgetic and muscle relaxant given continuosly during the procedure. MAP controlled between 90-110 mmHG. During operation hemodynamic relatively stable. Procedure completed after three hours. Considering preoperative awareness still good, not too long procedur, hemodynamic stable, and minimal brain edema or other brain tissue damaged patient extubated and transport to high care unit.

Key words: effective and efficient anesthesia, Fast tract anesthesia, intracerebral haemorrhage

JNI 2018;7 (2): 88-95 


\section{Pendahuluan}

Fast-tract anesthesia setelah operasi kepala memiliki beberapa keuntungan termasuk salah satunya adalah mengetahui komplikasi pasca operasi, kurangnya pelepasan katekolamin dan yang pasti mengurangi biaya untuk ICU. Namun peningkatan tekanan darah saat ekstubasi merupakan hambatan yang tidak dapat dihindari yang dapat menyebabkan komplikasi intrakranial seperti perdarahan berulang dan edema serebri. Lebih jauh lagi kondisi hiperkarbia dan hipoksia dapat terjadi pada kondisi hipoventilasi yang terjadi akibat obat anestesi yang digunakan dan terjadi pada periode awal setelah ekstubasi. Karena itu keputusan untuk ekstubasi segera harus bersifat individual dan sudah dipersiapkan dan direncanakan sejak preoperatif. ${ }^{1-3}$

Proses fast-track anestesi dikenalkan pertama kali oleh Professor Hendrik Kehlet di Denmark pada pasien yang menjalani operasi Colon pada awal periode 1990 an dengan tujuan agar pasien dapat mengurangi komplikasi yang terjadi, penggunaan ruang rawat intensif dan pasien dapat segera kembali ke rumah dan kembali dalam kehidupannya setelah melalui proses pembedahan. ${ }^{4}$ Pada fast-track anestesi digunakan berbagai teknik anestesi atau multi modal anestesi dan obat-obat anestesi kerja pendek dan menengah yang bertujuan mempercepat pemulihan pasca bedah. Rumah sakit yang memulai fast-track ini telah menunjukkan angka yang fantastis dalam menurunkan lama tinggal di rumah sakit. ${ }^{1,4}$

Pada fast-track anestesi ini seorang anestesiolog bertambah perannya tidak lagi terbatas hanya memberikan ruang kerja yang baik pada ahli bedah tetapi berperan penuh mengendalikan kondisi pasien selama perioperatif hingga seluruh kondisinya akan terkendali yang akan berujung pada waktu pulang yang lebih cepat dan mengurangi penggunaan ruang rawat intensif. ${ }^{4}$

Stroke hemoragik atau stroke perdarahan atau intracerebral hemorrhage adalah perdarahan spontan non trauma yang terjadi di dalam parenkim otak. Intracerebral hemorrhagic (ICH) terjadi pada sekitar 20 dari 100.000 penduduk setiap tahunnya. Merupakan gambaran 10-15\% dari seluruh stroke dan memiliki mortalitas dan morbiditas lebih tinggi dari pada subarachnoid hemorrhage dan infark cerebri. ${ }^{5}$ Tipikal stroke hemoragik adalah sepuluh tahun lebih muda dari pasien stroke iskemik. Kebanyakan perdarahan pada ICH adalah subkortikal dan lebih dari $50 \%$ dari perdarahan ICH spontan terjadi di ganglia basalis. Penderita dengan risiko tertinggi terjadinya ICH adalah laki-laki, usia lanjut, ras Afrika, Amerika, dan Asia. Hal ini berkaitan dengan perubahan pembuluh darah serebral sesuai dengan perubahan usia pada usia lanjut ras Afrika, Amerika, dan Asia. Perubahan pembuluh darah serebral seiring dengan bertambahnya usia menyebabkan semakin lanjut usia semakin besar risiko terjadinya perdarahan intraserebral. ${ }^{5}$

Umumnya fast-track anestesi dikerjakan pada operasi elektif dan teknik pembedahan yang tidak rumit, beberapa tulisan menekankan pada operasi reseksi tumor supratentorial dan dengan berbagai intervensi yang dikerjakan pada periode preoperasi, intraoperasi dan pascaoperasi. ${ }^{4}$ Pada kasus ini akan diangkat sebuah kasus fast-tract anestesi yang dikerjakan pada operasi emergensi dan merupakan kasus perdarahan intraserebral.

\section{Kasus}

\section{Anamnesis}

Pasien datang ke rumah sakit dengan keluhan sakit kepala berat sejak 3 jam sebelum masuk rumah sakit. Pasien juga mengeluh mau muntah. Sebelumnya pasien memang sudah pernah stroke tahun 2013 dan hanya merasa kelemahan di bagian tubuh sebelah kiri yang seiring dengan waktu kelemahan nya hilang sendiri. Pasien menderita kencing manis dan hipertensi sudah lama dan minum obat secara tidak teratur. Terakhir rutin minum obat setelah stroke selanjutnya tidak minum obat lagi.

\section{Pemeriksaan Fisik}

Keadaan umum tampak sakit berat, gelisah tampak pasien memejamkan mata dan menggerak-gerakkan kepalanya terus menerus, GCS E3 M6V apasia, tekanan darah 180/100 $\mathrm{mmHg}$, frekuensi nadi $90-100 \mathrm{x} / \mathrm{m}$, frekuensi napas $14 \mathrm{x} / \mathrm{m}$, saturasi oksigen $97-99 \%$ dengan sungkup muka 8 liter/menit. Mallampati sulit dinilai, jantung paru kesan baik 
Status neurologi: Kesadaran E3M6Vapasia, pupil anisokor, kanan lebih besar dari kiri, refleks cahaya. Sensorik motorik baik, kiri lebih lemah dari yang kanan

$$
\frac{11115555}{11115555}
$$

Sistim saraf pusat kesan klinis normal

\section{Pemeriksaan Penunjang}

Foto thoraks kesan bronkopneumonia dd/ proses spesifik. CT-Scan tampak lesi berdensitas darah berbentuk bulat estimasi berukuran $5 \times 5 \times 4 \mathrm{~cm}$ dengan perkiraan volume $52 \mathrm{cc}$, disertai perifokal edema yang mengakibatkan penyempitan sulci dan sisterna disekitarnya pada lobus temporoparietal kanan serta pergeseran midline sejauh $0,5 \mathrm{~cm}$ ke kiri dan penyempitan ventrikel lateralis kanan.
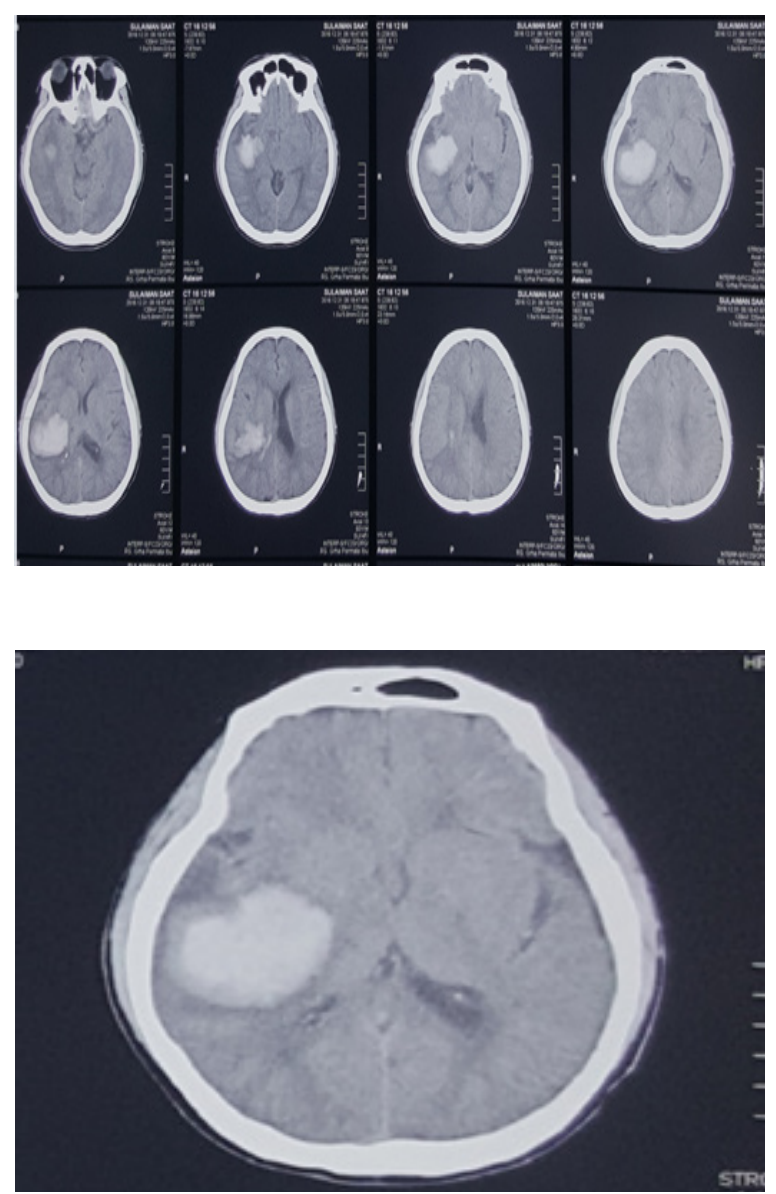

Gambar 1. Gambar CT-scan Kepala Preoperasi

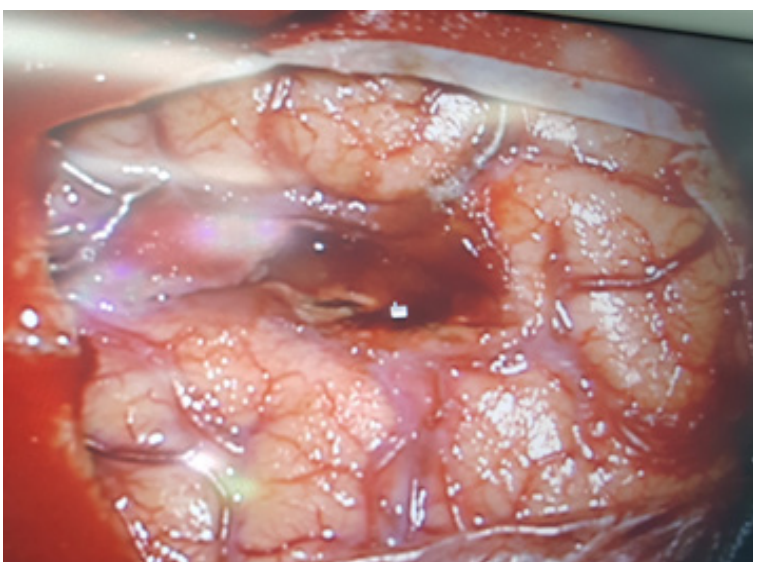

Gambar 2. Gambar area operasi

Kesan: perdarahan intraparenkimal estimasi volume 52 cc disertai perifokal edema di temporoparietal kanan dengan herniasi subfalcin ringan ke kiri. Saat di IGD pasien diberikan terapi Manitol 4x100cc, Fenitoin 3x100mg, Nicardipin $5 \mathrm{mg} / \mathrm{jam}$ dan dihentikan bila tekanan darah turun hingga 140/90 mmHg. Pasien direncanakan operasi kraniotomi evakuasi hematom cito.

\section{Pengelolaan Anestesi}

Pasien tidak sempat dilakukan kunjungan pre anestesi. Pasien sudah ada di ruang persiapan operasi saat ahli anestesi datang. Dilakukan anamnesis singkat dan pemeriksaan fisik didapatkan kesan pasien ASA 3 dengan hipertensi tidak terkontrol, DM dengan gula darah sewaktu terakhir 178 dan riwayat stroke tahun 2013.

Sebelum dilakukan koinduksi tekanan darah menunjukkan $180 / 110 \mathrm{mmHg}$, laju nadi $105 \mathrm{x} / \mathrm{m}$, saturasi 97\% dengan sungkup muka $8 \mathrm{1} / \mathrm{m}$. Diberikan premedikasi dengan ondasentron 4 $\mathrm{mg}$ dan lidokain intravena 60mg. Koinduksi dilakukan dengan midazolam $2 \mathrm{mg}$ dan fentanyl 75 mcg dilanjutkan dengan induksi dengan propofol $60 \mathrm{mg}$, setelah pasien tidak sadar dilakukan penyungkupan. Dilanjutkan dengan pemberian pelumpuh otot vecuronium $6 \mathrm{mg}$, diberikan fentanyl kembali sebesar 75 mikro dan ditambah propofol ulangan $30 \mathrm{mg}$. Laringoskopi langsung dilakukan saat tekanan darah 140/90 $\mathrm{mmHg}$, frekuensi nadi 90x/m. Tidak didapatkan peningkatan tekanan darah maupun frekuensi nadi yang bermakna. Pasien disambungkan dengan mesin anestesi dengan awitan fresh gas 
Grafik 1. Hemodinamik Pasien selama Operasi

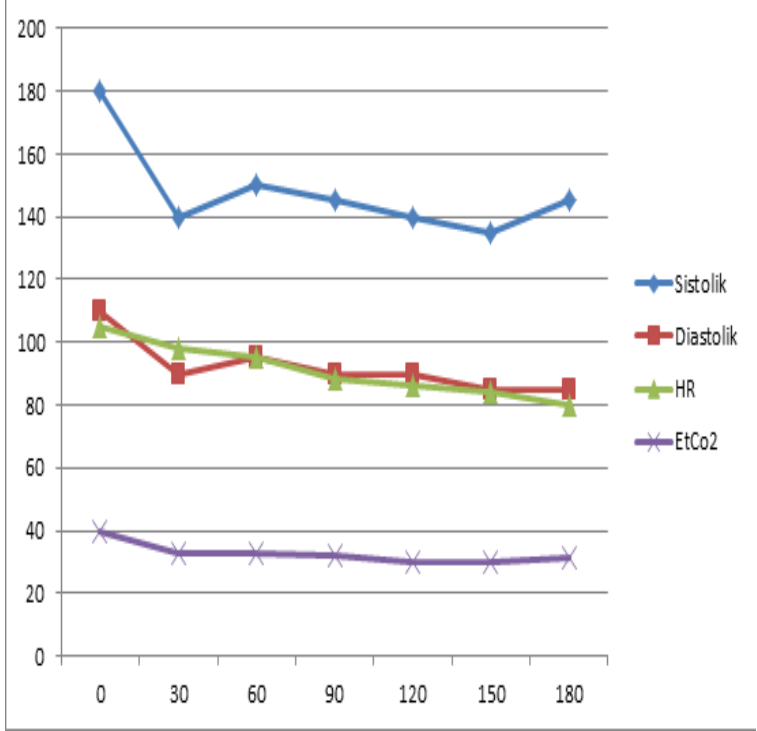

Tabel 1. ICH dan Prediksi Mortalitasnya. ${ }^{5}$

\begin{tabular}{|c|c|c|}
\hline & Nilai ICH & \\
\hline & Temuan & Nilai \\
\hline \multirow[t]{3}{*}{ GCS } & $3-4$ & 2 \\
\hline & $5-12$ & 1 \\
\hline & $3-15$ & 0 \\
\hline \multirow[t]{2}{*}{ Usia } & $\geq 80$ & 1 \\
\hline & $<80$ & 0 \\
\hline \multirow[t]{2}{*}{ Lokasi } & Infratentorial & 1 \\
\hline & Supratentorial & 0 \\
\hline \multirow[t]{2}{*}{ Volume } & $\geq 30$ & 1 \\
\hline & $<30$ & 0 \\
\hline \multirow{2}{*}{$\begin{array}{l}\text { Intraventricular } \\
\text { Blood }\end{array}$} & yes & 1 \\
\hline & no & 0 \\
\hline Total & & $0-6$ \\
\hline Nilai ICH & \multicolumn{2}{|l|}{30 hari mortalitas } \\
\hline 0 & \multicolumn{2}{|l|}{$0 \%$} \\
\hline 1 & \multicolumn{2}{|l|}{$13 \%$} \\
\hline 2 & \multicolumn{2}{|l|}{$26 \%$} \\
\hline 3 & \multicolumn{2}{|l|}{$72 \%$} \\
\hline 4 & \multicolumn{2}{|l|}{$97 \%$} \\
\hline 5 & \multicolumn{2}{|l|}{$100 \%$} \\
\hline 6 & \multicolumn{2}{|l|}{$100 \%$} \\
\hline
\end{tabular}

Tabel 3. Kondisi untuk Dilakukan Ekstubasi segera. $^{7}$

\begin{tabular}{ll}
\hline $\begin{array}{l}\text { Kondisi sistemik } \\
\text { Normotermi }\end{array}$ & $\begin{array}{l}\text { Kondisi otak } \\
\text { Normal } \mathrm{CMRO}_{2} \text { dan } \\
\text { CBF }\end{array}$ \\
$\begin{array}{l}\text { N o r m o v o l u m } \\
\text { normotensi } \\
\text { Normokarbi }\end{array}$ & $\begin{array}{l}\text { Normal ICP saat akhir } \\
\text { prosedur } \\
\text { Antiepilepsi } \\
\text { diberikan } \\
\text { Tidak } \\
\text { hipoosmolalitas } \\
\text { Hematokrit }>25 \%\end{array}$ \\
$\begin{array}{l}\text { Adekuat posisi head up } \\
\text { Tidak ada gangguan } \\
\text { pembekuan darah }\end{array}$ & $\begin{array}{l}\text { Persyarafan jalan napas } \\
\text { utuh }\end{array}$ \\
\hline
\end{tabular}

flow $1,6 \mathrm{1} / \mathrm{m} \mathrm{FIO} 260 \%$, sevofluran $1 \%$ vol. Untuk relaksan pasien dikontinyu dengan vecuronium $0,08 \mathrm{mg} / \mathrm{kg} \mathrm{bb} / \mathrm{jam}$ dan kontinyu propofol $2 \mathrm{mg} /$ $\mathrm{kgbb} / \mathrm{jam}$. Dilanjutkan dengan pemasangan akses vena besar dan arteri line. Termometer dipasang intraoral terlihat suhu sekitar 36.5C. Saat akaninsisi diberikan bolus fentanyil $50 \mathrm{mcg}$. Operasi berlangsung selama dua setengah jam. Selama intraoperatif hemodinamik relatif stabil. Hanya suhu tubuh yang terlihat terlalu rendah. Berdasarkan termometer intraoral suhu badan tercatat di 35,8 derajat $\mathrm{C}$.

Selama prosedur berlangsung fentanyl diberikan intermitten dan propofol disesuaikan dengan tingkat tekanan darah sistoliknya. Tekanan darah sistolik saat induksi masih sekitar $180 \mathrm{mmHg}$ dan sistolik terrendah dipertahankan $140 \mathrm{mmHg}$. Selama prosedur drip nicardipin tidak dilanjutkan. Gula darah intraoperatif dikontrol perjam saat mulai gula darah sewaktu diperiksakan sebesar $230 \mathrm{mg} / \mathrm{dL}$, diberikan drip insulin sebesar 2 unit/ jam jam pertama dilakukan pemeriksaan kembali didapat gula darah sewaktu sebesar $200 \mathrm{mg} / \mathrm{dL}$, insulin drip dipertahankan dengan 2 unit/jam. Satu jam berikutnya dilakukan pemeriksaan kembali didapat hasil $180 \mathrm{mg} / \mathrm{dL}$. Satu jam kemudian dilakukan pemeriksaan kembali dan didapat gula darah sewaktu sebesar $180 \mathrm{mg} / \mathrm{dL}$. Setelah ekstubasi gula darah diperiksa kembali dan didapatkan hasil sebesar $190 \mathrm{mg} / \mathrm{dL}$. Drip 
Tabel 4. Prosedur untuk Ekstubasi segera Pasca Kraniotomi.?

\begin{tabular}{|c|c|}
\hline $\begin{array}{l}\text { Cek list sebelum } \\
\text { ekstubasi }\end{array}$ & $\begin{array}{l}\text { Saran proses } \\
\text { membangunkan pasien }\end{array}$ \\
\hline \multirow{5}{*}{$\begin{array}{l}\text { Kesadaran preoperatif } \\
\text { baik }\end{array}$} & Siapkan untuk ekstubasi \\
\hline & $\begin{array}{l}\text { Stop opioid jangka } \\
\text { panjang atau menengah } \\
60 \text { menit sebelum } \\
\text { extubasi }\end{array}$ \\
\hline & $\begin{array}{l}\text { Obat obat anestesi sudah } \\
\text { minimal atau di stop saat } \\
\text { tutup kulit }\end{array}$ \\
\hline & $\begin{array}{l}\text { Pelumpuh otot sudah } \\
\text { turun hingga } 2 / 4 \text { atau } \\
\text { antagonis diberikan saat } \\
\text { akan ekstubasi }\end{array}$ \\
\hline & $\begin{array}{l}\mathrm{Pa} \mathrm{co}_{2} \text { dinaikkan hingga } \\
\text { normo karbi }\end{array}$ \\
\hline $\begin{array}{l}\text { Operasi terbatas dan } \\
\text { tidak ada kerusakan } \\
\text { jaringan yang hebat }\end{array}$ & $\begin{array}{l}\text { Hindarkan rangsang } \\
\text { nyeri yang tidak perlu. } \\
\text { (head pin dilepas segera } \\
\text { sebelum extubasi) }\end{array}$ \\
\hline $\begin{array}{l}\text { Tidak ada pembedahan } \\
\text { fossa posterior yang } \\
\text { luas dan berdampak } \\
\text { pada saraf cranial 9-12 }\end{array}$ & $\begin{array}{l}\text { Hindarkan lonjakan } \\
\text { tekanan darah }\end{array}$ \\
\hline $\begin{array}{l}\text { Tidak ada reseksi } \\
\text { AV shunt yang luas, } \\
\text { atau minimal edema } \\
\text { jaringan otak. }\end{array}$ & Observasi pasien \\
\hline $\begin{array}{l}\text { Suhu tubuh } \\
\text { yang normal, } \\
\text { oksigenasi baik dan } \\
\text { cardiovaskular stabil }\end{array}$ & $\begin{array}{l}\text { Transport ke ICU atau } \\
\text { PACU }\end{array}$ \\
\hline
\end{tabular}

insulin 2 unit/jam dipertahankan hingga pasien dipindahkan ke perawatan intensif. Weaning dilakukan setelah prosedur selesai. Propofol di stop hanya disisakan sevofluran $1 \%$ vol total pemberian fentanyl $300 \mathrm{mcg}$ selama prosedur operasi. Setelah spontan diberikan reversal dengan sulphas atropin dan neostigmin. Untuk mencegah gejolak hemodinamik saat ekstubasi diberikan kembali lidokan $60 \mathrm{mg}$. Tekanan darah relatif stabil selama proses ekstubasi sedikit naik hingga 150/100 mmHg. Pasien dipindahkan ke ruang perawatan intensif. Untuk analgetik pascaoperasi diberikan Paracetamol 3x1000mg dan parecoxib 1x40 mg intravena.

\section{Pengelolaan di Ruang Rawat Intensif}

Pasien masuk ruang rawat intensif dengan mengantuk, kontak baik. Tekanan darah 160/100 $\mathrm{mmHg}$, frekuensi nadi $85 \mathrm{x} / \mathrm{m}$, frekuensi napas $14 \mathrm{x} / \mathrm{m}$, saturasi oksigen $100 \%$ dengan nasl kanul $4 \mathrm{l} / \mathrm{m}$. Pasien mendapat terapi manitol 4x150cc, fenitoin $3 \times 100 \mathrm{mg}$, meropenem $3 \times 1 \mathrm{~g}$, ranitidine $3 \times 1 \mathrm{amp}$, asam traneksamat $3 \times 500 \mathrm{mg}$, canderin 2x16mg, amlodipine $1 \times 10 \mathrm{mg}$. Tekanan darah setelah beberapa jam pascaoperasi melonjak hingga $200 / 120 \mathrm{mmHg}$, frekuensi nadi $80 \mathrm{x} / \mathrm{m}$, frekuensi napas $14 \mathrm{x} / \mathrm{m}$, saturasi oksigen $100 \%$ pasien tidak gelisah. Obat-obat tekanan darah oral belum diberikan pasien juga terlihat masih ngantuk akhirnya dijalankan nicardipin $5 \mathrm{mg} /$ jam dengan target sistolik 140-150 mmHg. Nicardipin terus dijalankan hingga obat hipertensi oral dapat diberikan. Hari ketiga pascaoperasi pasien dipindahkan ke ruang rawat masih dengan terapi anti hipertensi dan pada hari ke delapan pascaoperasi pasien pulang ke rumah dengan keluhan tidak bisa tidur dan sakit kepala yang masih terus dirasakan.

\section{Pembahasan}

Angka extubasi di dalam kamar operasi pasca craniotomy masih sangat rendah (35\%) sebagian besar masih dilakukan extubasi di ICU (56\%) dan umumnya masih menunggu hasil CT scan kontrol yang biasanya dilakukan 24 jam setelah operasi selesai. Disisi lain penundaan extubasi ini akan memperbesar biaya perawatan dan menimbulkan masalah baru pada pasien seperti tertundanya evaluasi neurologis dan resiko stroke berulang. ${ }^{8}$ Pasien datang ke IGD dengan keluhan sakit kepala dan peningkatan tekanan darah. Disamping pasien memang memiliki tekanan darah tinggi yang tidak terkontrol pasien ini mengalami peningkatan tekanan intrakranial. Pasien ini tidak buru buru diturunkan tekanan darah nya dengan obat anti hipertensi tapi dilakukan terlebih dulu CT-scan kepala hingga didapatkan efek desak ruang akibat penambahan volume darah di kepalanya. Penambahan volume mencapai $52 \mathrm{cc}$. Berdasarkan hasil CT brain ini lah diputuskan 
untuk dilakukan evakuasi hematom. Intracerebral hematom (ICH) skor dari pasien ini adalah dengan komponen GCS 1(GCS 5-12), komponen volume ICH 1 (> $30 \mathrm{cc}$ ), komponen lokasi supratentorial (0), komponen usia 0 (dibawah 80 tahun) komponen perdarahan intraventrikuler tidak ada $(0)$ berarti angka kematian 30 hari nya adalah $26 \%$. Pasien ini memiliki prognosis yang cukup baik. Pada pasien ini ditegakkan dengan status asa 3 berdasarkan hipertensi tidak terkontrol, diabetes mellitus dan riwayat stroke iskemik tahun 2013. Dua komorbid ini memiliki potensi untuk terjadi morbiditas dan mortalitas yang besar. Satu satunya cara agar dua komorbid ini tidak membahayakan adalah dengan memastikan dua komorbid ini dalam keadaan stabil.

Pasien ini diberikan terapi nicardipin $5 \mathrm{mg} / \mathrm{jam}$ dengan catatan bila tekanan sistolik $140 \mathrm{mmHg}$ maka nicardipin akan di stop. Ini dilakukan agar cerebral perfusion pressure (CPP) tetap terjaga dan tidak menyebabkan terjadinya hipoperfusi pada sel sel otak. CPP =MAP-ICP. Twekanan intrakranial walaupun tidak bisa diperkirakan kenaikannya secara pasti tapi dengan melihat klinis pasien pasti telah terjadi peningkatan tekanan intrakranial. CPP normal $50-70 \mathrm{mmHg}$, ICP normal sekitar 5-15 mmHg. Maka untuk mempertahankan agar CPP tetap dalam rentang normal aman untuk pasien ini diusahakan MAP sekitar 90-110 mmHg. Pasien ini masuk ke kamar operasi dengan GDS $178 \mathrm{mg} / \mathrm{dL}$ ini sesuai dengan target dibawah $200 \mathrm{mg} / \mathrm{dL}$ tetapi untuk tekanan darah masih 180/110 mmHg, ini memiliki potensi untuk terjadi komplikasi seperti terjadi stroke hemoragik berulang ataupun perubahan tekanan darah yang tidak stabil. Untuk menurunkan tekanan darah ini coba diberikan premedikasi dengan midazolam $2 \mathrm{mg}$ saat di ruangan persiapan. Pemberian ini ditujukan agar pasien tenang hingga terjadi penurunan tekanan darah. Selama menunggu penurunana tekanan darah diberikan loading cepat cairan ringer fundin dengan maksud agar mencukupi kebutuhan cairan pasien sebelum dilakukan induksi. Penurunan tekanan darah tidak terjadi hingga koinduksi tetap dilakukan dengan tekanan darah masih sekitar 180/110 mmHg. Pasien dilakukan laringoskopi langsung saat tekanan darah sistolik $140 \mathrm{mmHg}$ dan untuk mencegah terjadi lonjakan simpatis maka diberikan lidokain intravena $1 \mathrm{mg} / \mathrm{kgbb}$. Banyak cara untuk mencegah kenaikan tekanan darah akibat stimulasi simpatik seperti dengan spray lidokain, dengan preparat beta-2 agonis, dengan fentanyil dosis tinggi atau pun dengan beta blocker. Pada pasien ini dipilih dengan pemberian lidokain intravena karena lidokain intravena yang paling sering dilakukan. Sedangan preparat beta-2 agonis atau beta bloker tidak dimiliki oleh rumah sakit. Untuk menggunakan fentanil dosis tinggi tidak saya berikan karena direncanakan untuk ekstubasi di akhir prosedur. Intraoperatif tekanan darah sistolik diusahakan dipertahankan sekitar 140-150 mmHg. Dipertahankan dengan drip propofol $2 \mathrm{mg} / \mathrm{kgbb} / \mathrm{jam}$ dan sevofluran 1\%vol, sedangkan fentanyl diberikan secara intermitten. Pelumpuh otot diberikan secara kontinyu dengan vecuronium $0,08 \mathrm{mg} / \mathrm{kgbb} / \mathrm{jam}$. Target sejak awal sejak pembiusan dimulai adalah pasien extubasi dan dirawat di HCU. Untuk obat obat yang digunakan dipilih yang kerja menengah atau pendek. Seperti pemilihan fentanyl karena memang kerja pendek dan tidak diberikan secara kontinyu, untuk relaksan juga pilihannya adalah vecuronium, pelumpuh otot kerja menengah dan tidak mengganggu hemodinamik pasien. Untuk sedasi digunakan propofol dan gas sevofluran, digunakan sevofluran agar pasien dapat dibangunkan dalam tujuh menit setelah gas anestesi dihentikan. Midazolam diberikan sebesar $2 \mathrm{mg}$ dengan maksud sebagai anxiolitik. Untuk sedasi tidak menggunakan preparat barbiturat karena direncanakan untuk ekstubasi, pada beberapa kepustakaan barbiturat dapat menghambat ekstubasi, kecuali memang telah direncanakan untuk dilakukan barbiturat koma.

Setelah dua setengah jam operasi berakhir dan dilakukan persiapan untuk ekstubasi. Pelumpuh otot telah dihentikan sejak operator menutup duramater. Hingga diperkirakan durasi pelumpuh otot telah habis saat akan ekstubasi. Propofol juga di stop setelah menutup kulit dan untuk sedasinya dipertahankan dari sevofluran saja. Dilakukan weaning pasien dan setelah spontan diberikan reversal dengan sulfas atropine dan neostigmine. Setelah napas spontan pasien baik, diberikan bolus lidokain $1 \mathrm{mg} / \mathrm{kgbb}$. Pemberian ini dimaksudkan 
untuk menekan lonjakan simpatik yang akan terjadi saat dilakukan ekstubasi. Banyak cara untuk menekan reflex simpatik akibat ekstubasi ini tapi yang paling memungkinkan adalah dengan penggunaan lidokain. Tidak ada beda antara balans anestesia dengan total intravenous anesthesia untuk waktu ekstubasi cepat. ${ }^{6}$ Bahkan penggunaan opioid (remifentanil, fentanyl dan sulfentanil) juga tidak berbeda dalam waktu ekstubasi. $^{6}$

Penelitian multi variat yang dilakukan di Thailand menyatakan penggunaan balance anesthesia lebih cepat dalam ekstubasi dibandingkan dengan TIVA. ${ }^{8}$ Pertimbangan kenapa dilakukan ekstubasi pada pasien ini adalah kondisi preoperatif pasien baik, kesadaran dan hemodinamik masih baik, normotensif, normovolemia, normoglikemia, operasi tidak lama, perdarahan relatif sedikit dan tidak ada kerusakan pada saraf kranial. ${ }^{1}$ Dari penelitian yang multi variat yang dikerjakan di Thailand didapatkan bahwa faktor yang mempengaruhi untuk dilakukan ekstubasi di dalam kamar operasi hanya ada/tidaknya edema cerebri, tingkat GCS dan ASA pasien. ${ }^{8}$ Pascaoperasi pasien dirawat di ruang $\mathrm{HCU}$ dengan target untuk pengawasan hemodinamik. Harapannya dalam 1-2 hari pasien dapat pindah ke ruangan asalkan tekanan darah stabil, diabetes mellitus terkontrol dan perdarahan ulang tidak terjadi.

Pada pasien ini tidak menggunakan tekhnik regional apapun karena kesempatan yang tidak ada tetapi sebenarnya teknik regional anaestesi akan sangat berguna pada fast-track anesthesia. Tehnik scalp block dapat menjadi pilihan untuk sebuah prosedur kraniotomi. ${ }^{9,10}$ Scalp block dengan menggunakan bupivacain $0,25-0,5 \%$ terbukti lebih superior dari tekhnik infiltrasi yang sering dilakukan oleh operator bedah saraf. ${ }^{9}$ Penggunaan fentanyl intraoperatif akan jauh berkurang. Tetapi penggunaan scalp block untuk pain management pascaoperasi masih harus diteliti lagi karena pada beberapa jurnal disebutkan penggunaan scalp block tidak mengurangi penggunaan morphin untuk mengurangi nyeri pasca operasi kraniotomi. ${ }^{10}$

\section{Simpulan}

Prosedur fast-track anestesi ini sangat menguntungkan karena mengurangi morbiditas dan mortalitas dan mengurangi penggunaan ICU yang berujung pada lama tinggal di rumah sakit dapat dikurangi. Untuk dapat melakukan fasttrack anestesi maka penggunaan obat-obatan dan teknik anestesi harus efektif dan efisien.

Obat-obat anestesi seperti analgetik dan pelumpuh otot kerja pendek dan menengah sangat membantu untuk dilakukan fast-track anestesi ini. Disamping penggunaan teknik anestesi yang efektif dan efisien. Kondisi preoperatif dan intraoperatif dari pasien akan sangat menentukan apakah fast-tract anestesi dapat dilakukan atau tidak. Fast-track anestesi dapat dilakukan pada semua jenis pembedahan kepala dan tidak terbatas pada operasi tertentu saja asalkan syarat syaratnya terpenuhi.

\section{Daftar Pustaka}

1. Nivatpunim $P, \quad$ Srisuriyarungrueng $S$, Saimuey P, Srirojanakul W. Factors affecting delayed extubation after intracranial Surgery in Siriraj Hospital. SMJ 2010 ; 62 (2): 119-23

2. Bhagat H, Dash HH, Bithal PK, Chouhan RS, Pandia MP. Planning for early emmergence in neurosurgical patients:a randomized prospective trial of low dose anesthetics. Anesth analg. 2008.Oct;107(4):1348-55

3. Bruder NJ. Awakening management after neurosurgery for intracranial tumors. Current Opinion Anesthesiology.2002 Oct;15(5):477-82

4. White PF, Kehlet H, Neal JM, Schricker T, Carr DB, Carli F. The role of the anesthesiologist in fast track surgery: from multi modal analgesia to perioperative medical care. Anesth Analg. 2007;104:138096.

5. Hemphill JC, Bonovich DC, Besmertis L, Manley GT, Johnston SC. The ICH score a simple, reliable grading scale for intracerebral 
hemorrhage. Stroke 2001;32: 891-97.

6. Ayrian E, Kaye AD, Varner CL, Guerra C, Vadivelu N, Urman RD, Zelman V, Lumb PD, Rosa G, Bilotta F. Effect of anesthetic management on early postoperative recovery, hemodynamic and pain after supratentorial craniotomy. J Clin Med Res. 2015;7(10):73141.

7. Bruder N, Ravussin P. Recovery from anesthesia and postoperative extubation of neurosurgical patients:a review. J Neurosurg anesthesiol 1999; 11 (4): 282-93.

8. Saringcarmkul A, Suwannachit S, Punjasawodwang Y. Factors associated with operating room extubation after emergency craniotomy. Jmed. Assoc Thai 2016;99(8): 933-9.

9. Geze S, Yilmaz AA, Tuzuner F. The effect of scalp block and local infiltration on hemodynamic and stress response to skull pin placement for craniotomy. Eur $\mathrm{J}$ anesthesiol 2009:26: 298-303.

10. Tuchinda L, Somboonviboon W, Supbornsing K, Worathongchai S, Limutaitip S. Bupivacain scalp nerve block: hemodynamic response during craniotomy, intraoperative and post operative analgesia. Asian Biomed. 2010; 4 (2):243-251. 